\title{
Effect of Time of Nitrogen Application on the Sucrose Content of Sugarcane Ratoons
}

\author{
George Samuels and Severiano Alers-Alers ${ }^{1}$
}

\section{INTRODUCTION}

Most agronomists will state that, to avoid lowering sucrose-percent-cane values, nitrogen should never be applied any later than 6 to 8 months before harvesting sugarcane. Thus the grower has a period of from 4 to 6 months to apply nitrogen to his 12-month ratoon crop after the previous crop has been harvested. If this were true, the cane-grower would have time enough to be able to finish most of his harvesting operations before he began the task of fertilizing his ratoons. With the scarcity of farm labor, such a distribution of operations would be a welcome one. In fact, many cane growers in Puerto Rico have been forced by labor shortages to apply their nitrogen to ratoons as late as 4 to 5 months after the cutting of the previous crop.

Unfortunately, the rule-of-thumb of leaving 6 to 8 months from the time of nitrogen application to harvesting the cane does not seem to work well in obtaining higher yields of sucrose-percent-cane. Recent experiments conducted by this Agricultural Experiment Station have shown that nitrogen applied to ratoons when over 2 months of age can decrease the sucrose content of the sugarcane when harvested at 12 months of age.

\section{PROCEDURE}

The experiments for this study on time of applying nitrogen to ratoons were conducted on P.R. 980 ratoons growing on a Vega Baja silty clay in the Humid Cane Zone of Río Piedras. The Vega Baja silty clay is a poorly drained soil of the river flood plains which lie slightly above normal river overflow, but during exceptional high water it is flooded. The surface soil to a depth of 8 or 10 inches is friable light-brown or grayish-brown granular acid (pH 5.1) silty clay. This layer changes abruptly to a plastic mediumcompact mottled yellowish-brown, gray, and red silty clay, or clay subsoil which continues to considerable depth and becomes slightly more mottled and more acid with depth.

The experiments covered two ratoons harvested in 1962 and two in 1963. All treatments were replicated eight times in a balanced lattice design. The treatments used and the results are given in table 1.

The plot size was 9 feet wide by 24 feet long, which gave an area of one

${ }^{1}$ Agronomist and Assistant Agronomist, respectively, Agricultural Experiment Station, University of Puerto Rico, Río Piedras, P.R. 
two-hundredths of an acre per plot. The plot had two rows with 3-eye sugarcane seed-pieces laid on the hottom of the furrow at 1-foot intervals and covered with soil. This gave a rate of planting of about 9,600 seedpieces per acre. The plant crop and first ratoon were used in a time-ofplanting experiment to be reported later. The second and third ratoon crops were used in the work reported herein.

The second ratoon crops for 1961-62 were harvested on June 5 and June 27, 1962, at ages of 12 months, and the third ratoon June 1 and June 4, 1963 , at ages of 12 months.

TABLE 1.-The influence of time of nitrogen application on yields of P.R. 980 sugarcane raloons

\begin{tabular}{|c|c|c|c|c|c|c|c|}
\hline \multirow{2}{*}{ Treatment No. } & \multicolumn{3}{|c|}{$\begin{array}{l}\text { Fertilizer treatment } \\
\text { applied per acre }\end{array}$} & \multirow{2}{*}{$\begin{array}{l}\text { Age of cane } \\
\text { at fertilizer } \\
\text { application }\end{array}$} & \multirow{2}{*}{ Sucrose in cane } & \multirow{2}{*}{ Cane per acre } & \multirow{2}{*}{ Sugar per acre } \\
\hline & $N$ & $\mathrm{P}_{2} \mathrm{O}_{6}$ & $\mathrm{~K}_{2} \mathrm{O}$ & & & & \\
\hline & Pounds & Pounds & Pounds & Weeks & Percent & Tons & Tons \\
\hline 1 & 125 & 0 & 0 & 3 & 12.33 & 61 & 7.6 \\
\hline 2 & 125 & 0 & 0 & 9 & 12.03 & 65 & 7.9 \\
\hline 3 & 125 & 0 & 0 & 15 & 11.46 & 63 & 7.3 \\
\hline 4 & 125 & 0 & 0 & 21 & 11.31 & 57 & 6.4 \\
\hline 5 & 250 & 0 & 0 & 3 & 11.70 & 68 & 8.0 \\
\hline 6 & 63 & 0 & 0 & 3 & 12.32 & 56 & 7.0 \\
\hline 7 & 125 & 50 & 25 & 3 & 12.29 & 73 & 9.0 \\
\hline 8 & 125 & 50 & 25 & 21 & 11.14 & 65 & 7.3 \\
\hline 9 & 250 & 100 & 50 & 3 & 11.81 & 76 & 9.0 \\
\hline \multirow{3}{*}{\multicolumn{5}{|c|}{$\begin{array}{l}\text { Least significunt differences needed between } \\
\text { treatments at: } \\
\text { 5-percent level } \\
\text { 1-percent level }\end{array}$}} & & & \\
\hline & & & & & 0.59 & 10 & 1.3 \\
\hline & & & & & .79 & 18 & 1.7 \\
\hline
\end{tabular}

\section{RESULTS}

There was a significant decrease in the sucrose content of the ratoon cane with late application of nitrogen. The decrease was from 12.33 to 11.31 sucrose-percent-cane when nitrogen was applied at cane ages of 3 weeks as compared to 21 weeks.

Comparing the 3- and 9-week cane-age nitrogen applications, there was no significant decrease in sucrose content. However, nitrogen applied to the cane when 15 weeks old produced significantly lower sucrose than the application at 3 weeks. The 21 -week nitrogen application gave significant decreases in sucrose over the 3- and 9-week times of application.

Not only was the sucrose-percent-cane reduced with late nitrogen applications, but tons of cane per acre were reduced with the 21-week nitro- 
gen application. The combination of lower sucrose and cane tonnage gave significantly lower tons of sugar per acre when we compare the 21-week nitrogen application (treatment 4) with the 9-week nitrogen application (treatment 2). The withholding of nitrogen for a long period of 21 weeks seems to have retarded the cane growth to a point where it was never able to produce high cane tonnage in 12 months, and the cane it did produce was greener, not mature, and lower in sucrose.

The amount used was 125 pounds of nitrogen per acre in the form of ammonium sulfate. This application rate is not considered high for ratoon cane in Puerto Rico where ratoon nitrogen application rates average 150 pounds per acre.

When the nitrogen rate was doubled to 250 pounds per acre (treatment 5) its application at 3 weeks caused a decrease in sucrose and an increase in cane tonnage as compared with the 125-pound nitrogen treatment at 3 weeks. When the nitrogen was decreased to 63 pounds per acre (treatment 6), the sucrose remained the same as for the 125 pounds of nitrogen per acre (treatment 1), but cane tonnage decreased.

The use of nitrogen only, without adequate phosphates or potash, can cause unbalanced nutritional conditions in the cane plant. Thus, it is reasoned that later applications of nitrogen would not be as detrimental to sucrose production if adequate phosphate and potash were present. To test this idea, treatments were included in this experiment where phosphate and potash were added to insure the presence of phosphate and potash with the nitrogen. At a ratoon age of 3 weeks, 125 pounds of nitrogen per acre, with phosphates and potash (treatment 7), gave no higher sucrose than the same nitrogen application alone (treatment 1). Yet, tons of cane per acre were increased significantly because of the presence of the phosphate and potash. But the same 125 pounds of nitrogen per acre with phosphate and potash at 21 weeks (treatment 8) reduced the sucrose content of the cane as significantly as did nitrogen alone at 21 weeks (treatment 4). Thus, late applications of nitrogen to ratoons-15 weeks or later-reduce sucrose-percent-cane even when phosphate and potash are present.

\section{DISCUSSION}

Experiments in India ${ }^{2}$ and Venezuela ${ }^{3}$ have shown that applications of nitrogen no later than a cane age of 3 months appear to be best for sucrose

2 Mohan-Roa, N. V., and Narasemham, R. L., Some aspects of nitrogen nutrition of sugarcane in Andhara, Proc. Ninth Cong. Int. Soc. Sugarcane Technol. (India) 1 74-93, 1956.

3 Ortega, D., and Segura, G., Epoca de Aplicación de Nitrógeno en Caña de Azúcar, Jornadas Agronómicas III, Cagua, Univ. Central de Venezuela, Facultad de S. Agrónomicas, Maracay, Venezuela, 1962. 
production from 12-month cane. The results of the experiments just presented reveal that applications of nitrogen to a 12-month ratoon cane at age of 15 weeks or later caused significant decreases in the sucrose content of the sugarcane. There may also be decreases in cane tonnage if applications are made as late as 21 weeks. Thus, our sugarcane grower in Puerto Rico should apply his fertilizer nitrogen to ratoons no later than 3 months after cutting his previous crop, and preferably before the cane is 2 months old, if he wishes to prevent the sucrose in his sugarcane from declining.

\section{SUMMARY}

Two ratoon crops of P.R. 980 sugarcane were grown on a Vega Baja silty clay at Río Piedras, P.R., with nitrogen applied at different times. The results indicated that:

1. The applications of nitrogen to ratoons $\mathbf{1 5}$ weeks or older significantly reduced the sucrose content of the sugarcane when harvested at 12 months of age.

2. Late applications of nitrogen to ratoons, 15 weeks or later, reduced sucrose-percent-cane even when phosphate and potash fertilizers were present.

3. High nitrogen rates, 250 pounds $\mathrm{N}$ per acre, caused significant lowering of sucrose in a 3-week-old ratoon.

\section{RESUMEN}

En un suelo del tipo Vega Baja limoso-arcilloso en Río Piedras, se cultivaron dos cosechas de retoño de la variedad de caña P.R. 980, a las cuales se les aplicó nitrógeno a distintos intervalos. Los resultados indicaron que:

1. Las aplicaciones de nitrógeno a cañas de retoño de 15 semanas de edad, o aun mayores, redujeron significativamente el contenido de sacarosa cuando la caña se cosechó a los 12 meses de edad.

2. Las aplicaciones tardías de nitrógeno a cañas de retoño (a las 15 semanas o después) redujeron el porcentaje de sacarosa en la caña aún estando presentes abonos fosfatados y potásicos.

3. El nitrógeno aplicado en grandes cantidades (250 libras por acre) puede causar una reducción significativa de sacarosa en la caña de retoño de 3 semanas de edad. 